\title{
The Determinant of Inbound Tourism in China
}

\author{
Huiling Wang ${ }^{1} \&$ Junmin $\mathrm{Xi}^{1}$ \\ ${ }^{1}$ School of management, Jinan University, Guangzhou, Guangdong, China \\ Correspondence: Junmin Xi, School of management, Jinan University, Guangzhou, Guangdong, China. E-mail: \\ 1181252938@qq.com
}

Received: November 17, 2015

Accepted: December 17, 2015 Online Published: January 23, 2016

doi:10.5539/ijbm.v11n2p205

URL: http://dx.doi.org/10.5539/ijbm.v11n2p205

\begin{abstract}
We estimate the factors of inbound tourism in China by using a panel gravity model equation of 178 origin countries from 1995 to 2012. We find the cultural dummy variables like common language, common border and religion driving the tourism flows to China. Besides, the climate variables like annual average temperature and cloud cover play a significant factors in affecting the tourist arrivals in China. An interesting result we have found that, cloud has a positive and negative relationship in country of destination and origin respectively implying that, cloudy variable in the country of origin has a negative impact on international tourist flows in China. In the contrary, cloud variable is observed positive relation in China.
\end{abstract}

Keywords: China, gravity model, inbound tourism, factors

\section{Introduction}

China as the world's largest developing country, in the context of globalization of economy, complying with the trend of development of global tourism, with increasing GDP in the country and improving people's living standards continuously, which actively promotes the development of inbound tourism at the same time. From October 1st, 2013, "Tourism Law of People's Republic of China" has come into effect, which stipulates rights, obligations and responsibilities of each body. As a result, this law has contributed to create a favorable legal environment for the development of tourism. National Tourism Administration issued the "Guidance on developing inbound tourism" in 2007. The State Tourism Bureau proposed the "515 Strategy" at the national tourism working conference at the beginning of 2015, namely there are five goals, 10 action, 52 initiatives in detail proposed in this conference in order to develop inbound tourism market vigorously. With encourages and supports of series of policies, inbound tourism in China has also made remarkable achievements. Tourism infrastructure and service facilities have been improving, together with the tourist reception capacity. Besides, inbound tourist arrivals and tourism foreign exchange earnings are on the rise overall. Tourist arrivals are 10,160,400 passengers in 2000, increasing to 26.361 million passengers in 2014, and meanwhile foreign exchange earnings from tourism are 1.6224 trillion US dollars in 2000, increasing to $\$ 5.691$ trillion in 2014 accordingly. China Tourism Research Team of Future predicted the Chinese tourism trends from 2011 to 2020, 20 years in total, which stated the establishment of government public service system will rapidly expand from the economically developed areas to other developing areas or even the areas in poverty, and inbound tourism will break through stagnation at the beginning of the century.

\section{Literature Review}

Current researches related to the determinants of inbound tourism, are mainly from the perspective of economy to analyze effect of some factors on inbound tourism. The way of research is mostly econometric methods and causal analysis.

Loeb.PD (1982) analyzed the factors of the US international tourism demand which shows that the relative exchange rates, income levels, relative price levels, major sporting events, special events have an impact on international tourism demand. Muzaffer Uysal et al. (1984) studied the factors of inbound tourism demand of Turkey, which the mainly result focus on main income, prices, and exchange rates. Tell (2001) found by regression model, the number of port have a key effect on tourism arrival, while tourism resource endowment has few effect on tourism arrival. Teresa and Teodosio (2000) suggested per capita GDP, exchange rate and price play an important role in driving the inbound tourism flows in Spain. Besides, the research discussed the Gulf War as dummy variables, which showed the Gulf War played a negative significant on tourism arrival. However, the 
author had two doubts about his research. Firstly, the problem is about the selection of the variables, if the article was added some variables like income distribution, people's leisure time, tourists education and age distribution, the credibility of the model may increase; Secondly, the research didn't distinguish the type of tourists, as we know, the elasticity of sightseeing is greater than the elasticity of business travel, resulting in a lower credible result. Haiyan Songa et al. (2003) analyze travel costs, the economic situation (income level) of origin countries, reputation of Hong Kong and travel cost of competitive destination all of them play a significant role in affecting the tourism arrival in Hong Kong. Johan and Maria Santana Gallego (2013) based on the gravity model and dynamic panel data, made a research about the determinants of Africa-inbound and within-Africa tourism, and estimated and predicted inbound tourism flows of Africa in the future. The result showed that the income of destination and origin country, land size, partnering in a regional trade agreement and sharing a common border, language, religion or former colonial ties all increase tourist arrival to Africa. In addition, this paper also considered another explanatory variables, for example, trade between destination and origin country, investment, coastlines, religion, political stability these factors whether have a common border, the temperature, etc. which have influence on tourist arrival in Africa to some extent.

Domestic research on inbound tourism began from 1980s. The study on the determinants of inbound tourism mainly from the perspective of economy, especially very small quantitative researches. Wang Zhaofeng et al. (2012) analyzed the impact of major events on inbound tourism based on the theory of the bottom trend line, and the selection of statistical data from 1984 to 2010. The result showed different degree effects on inbound tourism according to the different types of events including emergencies negative impact on inbound tourism. Wang Liangju et al. (2012) built extensive tourism gravity model by panel data to study the impact of RMB appreciation on inbound tourism to China. As expected, the conventional variable like development of economic size in origin country, the population size of inbound tourism have a positive impact on tourist arrival in China. While RMB appreciation play a negative impact on inbound tourism in China.

\section{Data and Sources}

We select the origin countries across six continents namely, totally 178 countries including 42 European countries, 42 Asian countries, 33 United States of America (including North and South America), 14 countries of Australia, 46 African countries. The selection of origin countries are obtained from United Nations World Tourism Organization (UNWTO) where statistics show the number of tourists to China from these origin country.

Data of tourist arrivals was obtained from the United Nations World Tourism Organization (UNWTO), which the unit is million. The distance variable which we measure the capital circle distance between China and origin country, were taken from CEPII website, and the unit is kilometers. GDP per capita of origin countries and China, number of population as well as the relative purchasing power parity between origin countries and China were derived from the World Bank's World Development Indicators. The number of migrants between China and origin countries was obtained from the World Bank and bilateral migration database. The value of trade between origin countries and China was derived from the database orientation of IMF developing. The variables of annual average temperature and cloudy days of origin country and China were derived from the Tyndall Centre for Climate Change Research website. Dummy variables are defined in the model as follow: if sharing a common language between origin countries and China, we put the value 1 otherwise 0 . If there is a common border between origin countries and China, we put the value 1 otherwise 0 . The variable about if origin countries are landlocked, we put the value 1 otherwise 0 . Besides, if origin countries share a common religion with some part of China. we put value 1 otherwise 0 . All of data about dummy variables were derived from religion CIA World Facebook.

\section{Describe of Variables}

Variables are described as follows. In order to make the model reliable, we still include traditional variables in the model based on the theory of gravity model. GDP per capita in U.S. dollars is included in the regression reflects that countries with higher GDP purchase present better tourist potentials and infrastructure. Furthermore, GDP also reflects the level of economic development of the country. On the other hand economic development provides sustainable and strong socio-economic support for tourism in the country. From the point of view of origin countries, GDP per capita is an important material condition of tourism activities. Distance is a proxy for travel cost and travel time. The population size of origin country and growth rate are basic tourist source of China's inbound tourist. In general, the more population size in origin country, the greater tourist flows to China.

In addition, some new variables were considered in the model. Relative purchasing power parity is related with inflation, the bigger relative purchasing power parity they have, and the higher inflation in origin countries than China. As a result, the currency of origin countries depreciate in contrast to China. We estimate the climate 
variables including annual average temperature in origin countries and destination countries in the regression model. Temperature is a proxy of climate elements. Annual average temperature has been used which tends to have a closely correlation with monthly mean temperatures. Lise \& Tol found the most pleasant temperature for tourist was $21^{\circ} \mathrm{C}$. Thus, the change of temperature has an important impact on tourism demand and tourist's choice of destination. In addition, the cloud cover percentage of origin and destination countries is used to explain the tourism arrivals, because the higher percentage mass of cloud covering all or most of the sky in origin country deter tourist to take tourism activity and reduce number of tourist arrivals. Migration between country of origin and China is considered to have a positive effect on developing international tourism flows between countries. In general, the development of trade between countries tends to strengthen economic corporation between countries as well as increase the international tourism movement. The common language make much easier for tourist to obtain information about tourist destinations, which make tourists reduce barriers to communication with local residents, bringing the sense of security during the trip. Sharing a common border between countries may be more similar in lifestyle, language, culture and so on due to close geographical location. The advantage is short time and low transportation costs. Religion ties play a certain role in impacting the tourism demand. The common main religion between origin countries and China, means they have a common value judgments, national taboos, and less conflict between tourists and residents. Moreover tourists from landlocked countries which indicate land territory is surrounded by land (without river, ocean, lake and etc.), namely there is no coastline. It is observed that landlocked country tends to a low level economic development, weak awareness of tourism.

\section{Empirical Model and Analysis}

The gravity model comes from gravitational theory which is built by Isaac Newton originally in 1687 . The theory is described as the forces between two planets related with their distance and mass. The equation is as following:

$$
\mathrm{F}=\mathrm{G} \frac{m_{1} m_{2}}{r^{2}}
$$

In the beginning, social science chooses this model to describe trade flows between two countries as well as to calculate migrations and Foreign Direct Investment (FDI). Recently, some scholars find this equation is nicely suitable for the tourism, especially for the tourist flows. With the promotion of this equation, the economic size effect and boarder effect are found in estimate the trade flows and then as for the tourism, the effect such as temperature, colony, language, currency, population etc. are used into this model. The model is transferred step by step as following:

$$
\text { Exports }_{\mathrm{ij}}=\frac{1}{G D P_{w}} \frac{G D P_{i} G D P_{j}}{\text { Dist }_{i j}^{2}}
$$

The standard procedure for estimating a gravity equation (2) is simply to transform into natural logarithms functional form of all variables and obtain a log-linear equation that can be estimated by regression econometric model as follows:

$$
\operatorname{Ln} X_{i j}=\mathrm{a}+\beta_{1} \operatorname{LnGDP_{i}}+\beta_{2} \operatorname{LnGDP}_{j}+\beta_{3} \operatorname{LnDist}_{i j}+\gamma \delta_{i j}
$$

Due to estimate the bilateral tourism flows by introducing a set of climate variables, economic size and the other mutual ties variables. As for China, taking into account the data availability, therefore, following model is estimated:

$$
\begin{aligned}
& \text { LnTou }_{i j t}=\beta_{0}+\beta_{1} \text { LnDist }_{i j}+\beta_{2} \text { LnGDPpc }_{i t}+\beta_{3} \text { LnGDPpc }_{j t}+\beta_{4} \text { LnRelPPP }_{i j t}+\beta_{5} \text { Temp }_{i}+\beta_{6} \text { Landl }_{i}+\beta_{7} \text { Contig }_{i j}+\beta_{8} \text { Comlang }_{i j}+ \\
& \beta_{9} \text { LnMigr }_{i j t}+\beta_{10} \text { LnTrade }_{i j t}+\beta_{11} \text { Relig }_{i j}+\beta_{12} C_{l i}+\beta_{13} C l_{j t}+\beta_{14} \text { LnPop }_{i}+\beta_{15} \text { Temp }_{j}+\varepsilon
\end{aligned}
$$

Where, $\operatorname{Ln}$ represents the natural logarithm, i and $\mathrm{j}$ denotes origin country and China (destination) respectively, $\beta_{1}-\beta_{15}$ are parameters to be estimated, $t$ represents time, $\beta_{0}$ is a constant, $\varepsilon$ is a random error term. Definition of the variables used in the equation (4) represented in Table 1 below. 
Table 1. Definition of variables used in the model

\begin{tabular}{|c|c|}
\hline Variable & Definitions \\
\hline Tou $_{\mathrm{ijt}}$ & Dependent variable, denoting the number of tourist arrivals from country of origin to China at time $t$ \\
\hline Dist $_{\mathrm{ij}}$ & Great circle distance between the origin country and China \\
\hline $\mathrm{GDPpc}_{\mathrm{it}}$ & GDP Per capita of the origin country at time $t$ \\
\hline $\mathrm{GDPpc}_{\mathrm{jt}}$ & GDP per capita of China at time $t$ \\
\hline Pop $_{\text {it }}$ & Total population of the origin country at time $t$ \\
\hline $\operatorname{RelPPP}_{\mathrm{ijt}}$ & Relative purchasing power parity between origin country and China at time $t$ \\
\hline $\operatorname{Migr}_{\mathrm{ijt}}$ & Number of immigrants between origin country and China at time $t$ \\
\hline Trade $_{\mathrm{ijt}}$ & Trade volume between origin country and China at time $t$ \\
\hline Comlang $_{\mathrm{ij}}$ & Dummy variables, if origin country and China share the same language then the value takes 1 otherwise 0 \\
\hline Contig $_{i j}$ & Dummy variables, if origin country and China have a common border the value takes 1 otherwise 0 \\
\hline Temp $_{\mathrm{i}}$ & The annual average temperature in origin country \\
\hline $\mathrm{Temp}_{\mathrm{j}}$ & The annual average temperature in China \\
\hline Landl $_{\mathrm{i}}$ & Dummy variable, if origin country is landlocked, the value takes 1 otherwise 0 \\
\hline $\mathrm{cl}_{\mathrm{it}}$ & Cloud cover percentage of origin country \\
\hline $\mathrm{cl}_{\mathrm{jt}}$ & Cloud cover percentage of China \\
\hline Relig $_{\mathrm{ij}}$ & Dummy variable, if origin country and China share a common religion we put the value 1 , otherwise 0 \\
\hline
\end{tabular}

The panel data was found strongly balanced for period of 1995-2012. Table 2 represents panel data results estimated in Ordinary Least Squares (OLS) regression by using Stata 13.0 program.

Table 2. Statistic estimation result of determinant of inbound tourism in China

\begin{tabular}{lccll}
\hline Variables & Coefficient & t-test & P-value & Std. \\
\hline lndist $_{\mathrm{ij}}$ & -1.632234 & -26.88 & 0.000 & 0.0607212 \\
lngdppc $_{\mathrm{it}}$ & 0.0868379 & 3.23 & 0.001 & 0.0269066 \\
lngdppc $_{\mathrm{jt}}$ & 0.86264 & 13.31 & 0.000 & 0.0647981 \\
lnpop $_{\mathrm{it}}$ & 0.4841566 & 23.69 & 0.000 & 0.0204369 \\
lnrelppp $_{\mathrm{ijt}}$ & -0.5524747 & -6.60 & 0.000 & 0.0836479 \\
lnmigr $_{\mathrm{jit}}$ & 0.0697278 & 8.92 & 0.000 & 0.0078164 \\
lntrade $_{\mathrm{ijt}}$ & 0.1818552 & 10.87 & 0.000 & 0.0167313 \\
comlang $_{\mathrm{ij}}$ & 2.422544 & 9.55 & 0.000 & 0.25374 \\
contig $_{\mathrm{ij}}$ & 0.776832 & 7.25 & 0.000 & 0.1071891 \\
Temp $_{\mathrm{i}}$ & -0.022629 & -6.13 & 0.000 & 0.0036897 \\
$\mathrm{Cl}_{\mathrm{it}}$ & -0.2528087 & -14.24 & 0.000 & 0.0177489 \\
$\mathrm{Cl}_{\mathrm{jt}}$ & 0.3353928 & 2.26 & 0.024 & 0.148103 \\
Landl $_{\mathrm{i}}$ & -0.520808 & -8.58 & 0.000 & 0.0606757 \\
relig $_{\mathrm{ij}}$ & 0.363911 & 3.14 & 0.002 & 0.1157148 \\
Cons $_{\text {Number of obs }}$ & 6.011219 & 7.64 & 0.000 & 0.7864948 \\
$\mathrm{R}^{2}$ & 2407 & & & \\
$\mathrm{~F}_{\text {value }}$ & 0.8141 & & & \\
Prob $_{\text {Root } \mathrm{F}}$ & 806.09 & & & \\
$\mathrm{P}_{\text {-value range: }} \mathrm{P}<0.05$ & & & & \\
\hline
\end{tabular}

Source: Estimated in STATA 13 program.

The results of estimation are presented in Table 2. It is not difficult to notice that, the overall test model 
corresponding $\mathrm{p}$-values are statistically significant at $5 \%$. Broadly speaking, $\mathrm{R}^{2}=0.8141$ reports that the model explain a satisfactorily high $81 \%$ of variation in Chinese inbound tourism. We would say that almost every variable is significant and could explain the correlations between countries.

The distance plays a negative correlation between two countries, indicating that the longer distance they have, the less tourist arrivals there will be. Previous research suggested that destination is far away, which leaded to decrease the number of tourist arrivals, since tourists are discouraged by longer travel times and expected travel cost. Longer distance travel choice requires longer time and higher travel cost and indeed it reduced number of tourist arrivals and departures (Tol, Richard et al., 2012; Hamilton \& Bigano, 2006; Maria Santana \& J. Rossello, 2014) also have been found negative relationship of distance variable..

GDP per capita of both country of origin and China have a positive effect on international tourist arrivals and is statistically significance at 5\% level, which indicated that the higher GDP per capita in origin country and China, the greater tourism demand to China. From the perspective of origin countries, GDP per capita stands for individual or family's income level, which is the essential condition for tourist activities even related to the level of tourism consumption. From the perspective of China, GDP per capita reflects the level of economic development of China, which provides a strong support for tourism, for instance, improved transportation system and tourism infrastructure. The result show that mass tourists tend to attempt to travel or move to developed regions.

Number of population of origin countries has a positive impact and are statistically significant at $5 \%$ level. According to the coefficient, it suggested if the population size increase by $1 \%$, China's inbound tourist flow will increase by $48 \%$. The large population size in origin country means huge potential tourist market than the small size population in origin country.

The relative purchasing power parity plays a negative relationship in tourist arrival of China. Relative PPP is proposed by the Kassel, Swedish economist, in 1918, he reveals the changes in exchange rates caused by inflation. If the inflation rate of origin countries exceeds the rate of inflation of China. The higher relative PPP, the higher inflation in origin countries. Inflation make the currency of origin will depreciate relative to China, and vice versa. Typically, inflation will reduce the purchasing power of money, which is not conducive to the outbound tourism of origin countries.

Lnmigr $_{\mathrm{ijt}}$ coefficient is (0.0697278), indicating that the number of immigrants between two countries increased by one unit, and tourist arrivals increased by 0.07 units. It is generally considered that large number of immigrants in destination from origin country will drive tourist travel to the destination. After China having access to WTO, trade volume between China and other countries are getting closer increasingly. Many foreigners have an insight to huge Chinese product market, and even move to China to develop the business and live in China. Therefore, their family members or relatives visit each other across the border, which promote the development of Chinese inbound tourism to some extent.

Coefficient of trade volume between origin countries and China is (0.1818552), statistically significance and has a positive impact on number of tourist arrivals implying that higher volume of trade between country of origin and China increased by $1 \%$, lead to increase international tourist arrivals in China by $18 \%$. General speaking, the development of trade relations between countries give a worthy opportunity of getting to know closely in terms of bilateral trades and create some new employees, strengthen skills of foreign staffs which led a number of business people as well as families, relatives of the cross-border flow. As a result, it produces many different types of tourism activities, business tourism and travel, visit relatives and friends and other. In another side of advantages of bilateral trades are to advertise and attract people to travel abroad and these lead to effect in publicity like providing tour guide to foreign residents and open up tourist traveling desire in the country and increase the volume of trade as well as it can be contributed to developing of China's inbound tourism.

Comlang $_{\mathrm{ij}}$ whose coefficient is (2.422544), indicates sharing a common language have positive effects and are statistically significant at $5 \%$ level, which suggested that if origin country and China share a common language it will promote the development of China's inbound tourism. This is because the common language drives the tourist more easier access to information of tourist destination, reducing barriers to communication with local residents in the process of travel.

Common border dummy variable is also confirmed that, it has a largely positive effect on international tourism flows at $5 \%$ significance level. Furthermore, Contig $g_{i j}$ coefficient is $(0.776832)$, which indicating that if origin country and China share a common border promoting the development of China's inbound tourism. Typically, if two countries share a common border between residents and countries lead to be the same or similar lifestyle habits in those areas. Perhaps they have a common language, or relatively similar language, while short distance, 
low travel time, low transportation costs and less travel resistance.

Landl $l_{i}$ coefficients is $(-0.520808)$, it is a dummy variable indicating if origin country is a landlocked country, it lead to reduce China's inbound tourist flows by $52 \%$. Landlocked country is one whose land territory is surrounded by other countries, there is no coastline. For example, Kazakhstan, Mongolia and so on. So far, there are 44 landlocked countries in the world. Most of these landlocked countries have a laggard economy, which part of reasons is because there is no port, high trade costs due to transportation and technology level is relatively backward. In addition, the population size is relatively small and its economic pillars are mainly livestock and mining industries. The sense of tourism is weak, and the demand of outbound travel is less.

We tend to show how climate change really effect on sensitive tourism flows by compromising various climate variables as expected, regarding to temperature and cloudy variables both of them are statistically significant at $5 \%$ in the model. The coefficient of annual average temperature is (-0.022629) indicating that the higher annual average temperature in origin country, which lead to reduce tourist arrivals in China. According to data from Tyndall Centre for Climate Change Research from 1995 to 2012, China's annual average temperature is $6.9^{\circ} \mathrm{C}$. Tourists generally tend to go to the warmer destination. Therefore, in contrast to China's average annual temperature, if the origin country's average annual temperature is becoming relatively high, most of tourists of origin country tend to carry out domestic tourism, or travel to a medium warmer destination.

Cloud cover in origin country expected negative effect and is significant at $5 \%$ level, indicating that higher percentage mass of cloud covering all or most of the sky in origin country intend tourists to stay at home and this leads to reduce number of tourist arrivals. However, according to the coefficients $\mathrm{Cl}_{\mathrm{jt}}(0.3353928)$ and $\mathrm{Cl}_{\mathrm{it}}$ $(-0.2528087)$ are positive and negative respectively. As expected, the result confirm cloudy cover in origin countries have a negative effects on tourist arrival in China. Broadly speaking, cloudy weather may form like precipitation, it is not conducive to travel. But the cloud cover in China have a positive effects on tourism flows to China. Possible interpretation is because more days of cloudy the better temperature, precipitation and comfortable weather conditions to travel in China.

Coefficient of Relig $\mathrm{g}_{\mathrm{ij}}$ is $(0.4751792)$, which declare sharing the common religion between origin countries and China increasing the number of inbound tourism in China. In general, there are lots of different religions in China, Islam, Buddhism, Christianity etc. But there has a main religion in some country, for instance, there are lots of people believe in Buddhism in India. From the foreign perspective, even though there are many people believe in Christianity in China, followers of Buddhism still account for most of the believers. The common religion make the believers have a common value, less conflict, more understand, generating the religious travel.

\section{Conclusions and Policy Implications}

The current research examines the determinants of inbound tourism in China from 178 countries of origin to China as a destination over eighteen-year period (1995-2012). Based on gravity model, the impact of factors and other determinants on inbound tourism flows explained by economic size, distance between origin and China, climate variables, bilateral trade and immigrations as well other relative variables. As expected, Economic size of the origin and destination countries are positively related to international tourist arrivals, the circle distance play a negative coefficient in tourism arrivals in China. In other words bilateral international tourism flows would take place where distance between origin and destination is close and high economic size of the partner countries. Besides, the population size play a positive significant on tourist arrivals in China, which have a same result with the previous research.

Furthermore, common land border, sharing common language and religion are among the key factors of increasing number of inbound tourism in China. It should be noted that bilateral trades and number of immigration variables have a positive impact on inbound tourism in China implying that large number of bilateral trades and immigration can be increased number of tourist arrivals in China by $18 \%$ and $7 \%$ percent respectively, as a consequent, the share of bilateral trades between countries can be allocated a positive growth in China. Developing bilateral trades promote economic prosperity of each countries and improve the pipe of trade exchanges between China and the origin countries, for example getting closer partners, led the development of China's inbound tourism. Landlocked countries in origin countries observed a slow travel namely lower number of tourist arrivals, and is obviously has a negative impact on inbound tourism in China.

In addition, the annual average temperature variable of origin countries, cloudy cover in origin country and China, and the relative purchasing power parity factors have been found negatively relation on inbound tourism in China. An interesting result we have found that, cloudy has a positive and negative relationship in country of destination and origin respectively implying that, cloudy variable in the country of origin has a negative impact and is statistically significance at $1 \%$, implying that greater days of cloudy in the country of origin lead to reduce number 
of departures and tourists prefer to do holiday in host countries than travel in abroad, on the other hand it become a cause to decrease international tourist flows in China. In the contrary, cloud variable is observed positive relation in destination (China) country implying that more days of cloudy in China attract more tourist arrivals in the country because of more days of cloudy the better temperature, precipitation and comfortable weather conditions to travel.

Based on the results of the current research, Chinese government may further develop border tourism market and overseas Chinese tourism market. In addition, perhaps the administration department can consider to put emphasis on the origin countries whose relative purchasing power parity index much lower. We should also pay attention to effects of cultural factors like common language, common religion and so on. Moreover, by the platform of trade, we can contribute to the tourism arrivals in China.

\section{References}

Fourie, J., \& María, S. G. (2013). The determinants of African tourism. Development Southern Africa, 30(3), 347-366. http://dx.doi.org/10.1080/0376835X.2013.817302

Kulendran, N., \& Wong, K. K. F. (2011). Determinants versus Composite Leading Indicators in Predicting Turning Points in Growth Cycle. Journal of travel research, 50(4), 417-430. http://dx.doi.org/10.1177/0047287510373280.

Hamilton, J., \& Tol, R. (2007). The impact of climate change on tourism in Germany, the UK and Ireland: A simulation study. Regional Environmental Change, 7(3), 161-172. http://dx.doi.org/10.1007/s10113-007-0036-2

Loeb, P. D. (1982). International travels to the US: An econometric evaluation. Annals of Tourism Research, 9(1), 7-20. http://dx.doi.org/10.1016/0160-7383(82)90031-7.

Lise, W., \& Tol, R. S. J. (2002). Impact of climate on tourism demand. Climate Change, 55, 429-449. http://dx.doi.10.1023/A:1020728021446

Lin, V. S., Liu, A., \& Song, H. Y. (2015). Modeling and forecasting Chinese outbound tourism: An Econometric

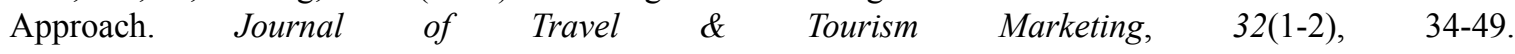
http://dx.doi.org/10.1080/10548408.2014.986011

Lien, D., Ghosh, S., \& Yamarik, S. (2014). Does the Confucius institute impact international travel to China? A panel data analysis. Applied Economics, 46(17), 1985-1995. http://dx.doi.org/10.1080/00036846.2014.889802

Lim, C. (1997). Review of international tourism-demand models. Annals of Tourism Research, 24, 835-849. http://dx.doi.org/10.1016/S0160-7383(97)00049-2.

Priego, F., Rosselló, J., \& Santana-Gallego, M. (2015). The impact of climate change on domestic tourism: a gravity model for Spain. Regional Environmental Change, 15(2), 291-300. http://dx.doi.org/10.1007/s10113-014-0645-5

Saayman, A., \& Saayman, M. (2008). Determinants of inbound tourism to South Africa. Tourism Economics, 14(1), 81-96. http://dx.doi.org/10.5367/000000008783554893

Wu, Q., Law, R., \& Xu, X. (2012). A sparse Gaussian process regression model for tourism demand forecasting in Hong Kong. Expert Systems with Applications, 39(5), 4769-4774. http://dx.doi.org/10.1016/j.eswa.2011.09.159

\section{Copyrights}

Copyright for this article is retained by the author(s), with first publication rights granted to the journal.

This is an open-access article distributed under the terms and conditions of the Creative Commons Attribution license (http://creativecommons.org/licenses/by/3.0/). 